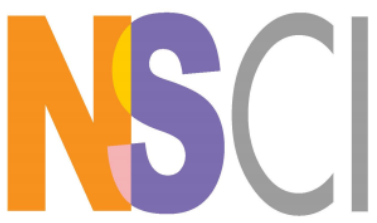

Current Perspectives on Medicinal and Aromatic Plants

An International Journal

ISSN: 2619-9645 | e-ISSN: 2667-5722

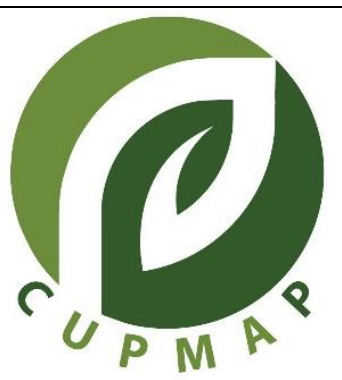

\title{
Phytochemical Screening and Biological Activity Analysis of Some Selected Medicinal Plants of Ilam District of Nepal
}

\author{
$\underline{\text { Anju BASNET }}$ (iD), Surya Kant KALAUNI* iD \\ Central Department of Chemistry, Tribhuvan University, \\ Postal code 44613, Kirtipur, Kathmandu, Nepal \\ *Corresponding author: skkaluni@gmail.com
}

\begin{abstract}
Nepal is considered as a natural storehouse of medicinal plants with aromatic and medicinal values, being a land of diverse topography with the different weather conditions. More than $75 \%$ of the total population of Nepal relies on the traditional medicines for their primary healthcare, and thus it is an important task to explore the chemical constituents and biological activities of plants grown in the local weather. So, we have selected ten medicinal plants as the experimental sample and extracted the contents in methanol by cold percolation method. The phytochemical screening revealed that glycosides, terpenoids, reducing sugars, polyphenols, and quinones were present in most of the plant extracts. In DPPH free radical scavenging test, the extracts of Nephrolepsis auriculata $(46.22 \mu \mathrm{g} / \mathrm{ml})$ and Rumex nepalensis $(48.59 \mu \mathrm{g} / \mathrm{ml})$ showed potent antioxidant activity. The extracts of N. auriculata and R. nepalensis contains the highest total phenolic and total flavonoid contents as $1076.73 \& 964.56 \mathrm{mg} / \mathrm{g}$ GAE and $40.8 \& 39.06 \mathrm{mg} \mathrm{QE} / \mathrm{g}$, respectively. The extract of Erythrina arborescens depicts significant antibacterial activity against the Gram-positive and Gram-negative bacteria. In brine shrimp lethality bioassay, the methanol extract of Zanthoxylum armatum $(6.3 \mu \mathrm{g} / \mathrm{mL})$ and Heracleum nepalense $(88 \mu \mathrm{g} / \mathrm{mL})$ shows considerable cytotoxicity as their LC50 values were found to be lower than $100 \mu \mathrm{g} / \mathrm{mL}$. The results endorsed the notion behind the use of traditional medicinal plants to treat various diseases. So, these plant extracts could be used for isolating the bioactive compounds that could be used in the discovery process of noble drugs in the future.
\end{abstract}

Key Words: Medicinal plants, antioxidants, phenolic, flavonoids, antimicrobial

(C) CUPMAP. All rights reserved.

\section{Introduction}

Cradled on the laps of the central Himalayan range, Nepal is sandwiched between two Asian giants, China in the North and India on three sides; South, East, and West. Nepal is considered as a natural storehouse of medicinal plants representing distinct on the distribution of various species of plants with aromatic and medicinal values due to its geographical diversity, variations in topography, altitude, climatic gradients, and biological resources (Nepal: General Info). Nepal is ranked 9th among the Asian countries for its floral wealth. More than 9000 species of floral plants (Kunwar et al., 2013) are estimated in Nepal of which about 1600-1900 species are medicinal and aromatic plants commonly used for the medicinal purpose (Ghimire, 2008; Acharya, 2014). More than $75 \%$ of the total population of Nepal relies on traditional 
medicine for their primary healthcare (Adhikary, 2011). Furthermore, $50 \%$ of Nepal's rural family's livelihoods and income depends on the collecting and trading of medicinal plants (Kunwar et al., 2011). Medicinal plants being the most reliable source to acquire a variety of novel herbal drugs, scientists working on infectious diseases have great interest to derive biologically active compounds from natural resources. (Dhote, 2015).Medicinal plants are an excellent source of biologically active compounds known as phytochemicals such as; phenolic acids, polyphenols, and flavonoids, alkaloids, tannins which shows different biological activities such as antioxidant, antimicrobial, cytotoxicity, and antitumor activities (Saxena, 2013). Antioxidants are the substances that protect cells against the deleterious effects of the reactive oxygen species (Sen, 2010), which are highly reactive unstable ions (hydrogen peroxide, free radicals). Reactive oxygen species (ROS) are the weapons in causing various chronic and life-threatening diseases: cardiovascular diseases, inflammation, heart stroke, cancer, ageing processes (Oliveira, 2009; Acharya, 2014). The phytochemicals, mainly phenolic and flavonoid compounds are useful free radical scavengers (due to phenolic hydroxyl group), prevent the action of ROS to damage cells, and act as powerful antioxidants. (Shahidi, 2010; Saxena et al., 2012). About two-thirds of plant species worldwide have medicinal values, and most of all are potent antioxidants. A bioactive natural antioxidant, mainly of plant origin has fewer side effects, eco-friendly, and locally available. Therefore, evaluation of the antioxidant property of the plants used in herbal medicine is necessary that could lead to the discovery of natural antioxidants with pharmacological values. (Kasote et al., 2015; Jamuna, 2012).

Antimicrobial agents help in minimizing the global problem of infectious (bacterial, fungal, virus) diseases (Manandhar, 2019). However, the development of multidrug resistance (MDR) strain in pathogenic bacteria and the presence of various side effects of certain antibiotics has created a more significant threat to public health (Abdalla et al., 2007). Medicinal plants have been recognizing as vast potential sources for antimicrobial drugs (Cavalieri et al., 2005; Zaidan, 2005). Therefore, it is imperative to give continuous effort on systematic screening of antimicrobial plant extracts to find noble compounds with the substantial capacity to act against multiresistant pathogenic bacteria and fungi and to understand better their properties, safety, and efficacy (Ullah, 2011).

People have been using plant and plant products for the healing of various diseases as medicine without knowing their chemical constituents and biological activities since prehistoric times (Yuan, 2016). Although most of the local communities of Nepal used traditional medicines to cure ailments, only limited research has been carried out to prove its use on a scientific basis. Thus, it essential to explore the chemical constituents and biological activities of plants and plant products, which influence human biochemistry in the medicinal plants for establishing a relation between traditional use and scientific meaning. In the present study, eight locally grown medicinal plants were chosen from Chamaita VDC of the Ilam district of Nepal based on traditional applications to assess their phytochemicals, antioxidant activity, and antibacterial potential.

\section{Material and Method}

\subsection{Collection of plant materials}

The fresh plant materials were collected in February 2016 from Chamaita VDC of the Ilam district based on their local medicinal uses and pharmacological importance as listed in Table 1 . The taxonomic identification of plants was made by Prof. Dr Suresh Ghimire, Central Department of Botany, Tribhuvan University, Kirtipur. 


\subsection{Preparation of plant extracts}

The collected fresh materials were washed under running tap water to remove the contaminations then clean parts were airdried in the shade for 28 days at room temperature. The dried materials were ground to powder using the electric grinder and stored in separate clean plastic bags for further use. One hundred grams of powder of each plant were extracted by cold percolation method in methanol. The powder was kept into conical flasks, and 500 $\mathrm{ml}$ methanol poured into each of the flasks and soaked for 72 hours at room temperature and filtered through clean cotton. The filtrate thus obtained was concentrated by using Rotary Evaporator. Thus obtained methanol extracts were kept in a separate beaker for drying and then stored in cold place by wrapping with aluminum foil until further use.

\subsection{Phytochemical screening}

The phytochemicals present in the methanol plant extracts were screened by following the procedure described by Prof. I. Ciulei (1982). The major groups of natural constituents present in each plant extracts were analyzed by the color reaction using specific reagents.

\subsection{Antioxidant Activity}

The antioxidant activity of each plant extracts was assessed by using 2, 2diphenyl-1-picrylhydrazyl free radical $(\mathrm{DPPH} \bullet$ ) scavenging method, as explained by Blois (1958) Ascorbic acid was used as a standard.

\subsection{Total phenolic content}

The total phenolic contents (TPC) of the plant extracts were studied by the FolinCiocalteu colorimetric method based on the oxidation-reduction reaction, as explained by Waterhouse (2001). Gallic acid is used as standard as it is less expensive and available in pure form.

\subsection{Total flavonoid content}

Total flavonoid contents (TFC) of the plant extracts were analyzed by aluminum chloride (AlCl3) colorimetric assay as described by Kalita, et al., (2013). Quercetin was used as a standard.

\subsection{Antibacterial Activity}

The antibacterial activity of the methanol extract of the plants was evaluated by the agar-well diffusion method. The potent antimicrobial plant extracts were determined by measuring the zone of inhibition (ZOI), according to Dingel et al. (1953).

\subsection{Brine Shrimp Bioassay}

The toxicity of the plant extracts was examined by brine shrimp bioassay by following the standard protocol given by Mayer et al., (1982). Bioactive compounds show toxicity towards brine shrimp larvae. 
Table 1: List of plants selected for the study with their traditional uses and \% yield in methanol

\begin{tabular}{|c|c|c|c|c|c|c|}
\hline S.N & Scientific Name & $\begin{array}{l}\text { Nepali } \\
\text { Name }\end{array}$ & $\begin{array}{l}\text { Used } \\
\text { Part }\end{array}$ & $\begin{array}{c}\text { Extraction } \\
\text { Yield } \\
(\%)\end{array}$ & $\begin{array}{l}\text { Altitude } \\
\text { (m) }\end{array}$ & Traditional Uses \\
\hline 1. & $\begin{array}{l}\text { Erythrina arborescens } \\
\text { Roxb. (Leguminosae) }\end{array}$ & Phaledo & $\begin{array}{l}\text { Plant } \\
\text { stem }\end{array}$ & 15.93 & $1500-3000$ & $\begin{array}{l}\text { Tooth-earache, joint } \\
\text { pain, } \\
\text { Inflammations, fever, } \\
\text { skin diseases (Baskar, } \\
\text { 2010) }\end{array}$ \\
\hline 2. & $\begin{array}{l}\text { Heracleum nepalense D. } \\
\text { Don (Apiaceae) }\end{array}$ & Chimfing & Seeds & 4.48 & $\begin{array}{l}1800-3700 \\
\text { (Shrestha, } \\
2019 \text { ) }\end{array}$ & $\begin{array}{l}\text { Tonic, Cold, cough, } \\
\text { diarrhea, body ache, } \\
\text { faint (Joshi, 2016) }\end{array}$ \\
\hline 3. & $\begin{array}{l}\text { Ligusticopsis wallichiana } \\
\text { DC. (Apiaceae) }\end{array}$ & Bhutkesh & $\begin{array}{l}\text { Whole } \\
\text { plant }\end{array}$ & 30.41 & $\begin{array}{l}2700-4800 \\
\text { (Shrestha, } \\
\text { 2019) }\end{array}$ & $\begin{array}{c}\text { Faints, diarrhea, } \\
\text { vomiting, stomachache, } \\
\text { cough, fever (Devkota, } \\
\text { 2018) }\end{array}$ \\
\hline 4. & $\begin{array}{l}\text { Nephrolepis auriculata } \\
\text { L. (Nephrolepidaceae) }\end{array}$ & Paniamala & $\begin{array}{l}\text { Whole } \\
\text { plant }\end{array}$ & 3.12 & $200-500$ & $\begin{array}{c}\text { Cold, cough, fever, } \\
\text { indigestion, liver and } \\
\text { skin disorder (Rukmini, } \\
\text { 2014) }\end{array}$ \\
\hline 5. & $\begin{array}{l}\text { Phytolacca acinosa } \\
\text { Roxb. (Phytolaccaceae) }\end{array}$ & Jaringo & $\begin{array}{l}\text { Whole } \\
\text { plant }\end{array}$ & 8.88 & $\begin{array}{l}\text { 500-3400 } \\
\text { (Pliszko, } \\
\text { 2018) }\end{array}$ & $\begin{array}{l}\text { Indigestion, eye } \\
\text { disorder, body ache } \\
\text { (Parajuli, 2013) }\end{array}$ \\
\hline 6. & $\begin{array}{l}\text { Rubia cordifolia L. } \\
\text { (Rubiaceae) }\end{array}$ & Majhito & $\begin{array}{l}\text { Plant } \\
\text { body }\end{array}$ & 11.46 & $\begin{array}{c}1,200- \\
2,100 \\
\text { (Shrestha, } \\
\text { 2019) }\end{array}$ & $\begin{array}{c}\text { Wounds, skin } \\
\text { infections, leprosy, } \\
\text { diarrhea, ulcers, snake } \\
\text { bite (Meena, 2010) }\end{array}$ \\
\hline 7. & $\begin{array}{l}\text { Rumex nepalensis } \\
\text { Spreng. (Polygonaceae) }\end{array}$ & Halhale & $\begin{array}{c}\text { Rhizom } \\
\text { e }\end{array}$ & 12.39 & $\begin{array}{c}\text { 1,200- } \\
4,200 \\
\text { (Shrestha, } \\
2019 \text { ) }\end{array}$ & $\begin{array}{l}\text { Dysentery, body pain, } \\
\text { colic ulcer, Jaundice, } \\
\text { skin sores (Kumar et.al, } \\
2011 \text { ) }\end{array}$ \\
\hline 8. & $\begin{array}{l}\text { Zanthoxylum armatum } \\
\text { Linn. (Rutaceae) }\end{array}$ & Boke timor & Bark & 13.39 & $\begin{array}{l}1100-2500 \\
\text { (Shrestha, } \\
2019 \text { ) }\end{array}$ & $\begin{array}{l}\text { Toothache, fever, } \\
\text { stomach ache, low } \\
\text { blood pressure } \\
\text { (Kayat, 2016) }\end{array}$ \\
\hline
\end{tabular}

\section{Results and Discussions}

\subsection{Phytochemical screening}

The qualitative estimation of phytochemicals present in crude methanol extract of selected plant materials is shown in Table 2, which depicts that glycosides and terpenoids were present in all the extracts. Reducing sugars, polyphenols, and quinones were present on most of the plant extracts. Flavonoids and saponins were present in the extracts of R. cordifolia, R. nepalensis, and N. auriculata. Alkaloids were present only in Z . armatum and E. arborescens. The variation of the phytoconstituents of the same plant species (data present in the literature) may be due to altitude divergence of plants, environmental factors, extraction methods, sample collection time as well as chemical grades and laboratory setup. 
Table 2: Phytochemical analysis of methanol plant extracts. Key: (+): Present (-): Absent

\begin{tabular}{|c|c|c|c|c|c|c|c|c|c|c|}
\hline S.N. & Name of the Plants & Alk. & Coum. & Flav. & Gly. & Polyp. & Quin. & Red.S. & Sap. & Terp. \\
\hline 1. & Erythrina arborescens & + & - & - & + & - & + & + & - & + \\
\hline 2. & Heracleum nepalense & - & - & - & + & - & - & - & - & + \\
\hline 3. & Ligusticopsis wallichiana & - & - & - & + & + & + & + & - & + \\
\hline 4. & Nephroleps auriculata & - & + & + & + & + & - & + & + & + \\
\hline 5. & Phytolocca acinosa & - & - & - & + & - & + & + & - & + \\
\hline 6. & Rubia cordifolia & - & - & + & + & - & + & - & + & + \\
\hline 7. & Rumex nepalensis & - & + & + & + & + & + & + & + & + \\
\hline 8. & Zanthoxylum armatum & ++ & + & - & + & + & - & + & - & + \\
\hline
\end{tabular}

Key: Alk. = Alkaloids, Coum. = Coumarins, Flav. = Flavonoids, Polyp. = Polyphenols, Qui. = Quinones, Red. S = Reducing Sugar, Sap. = Saponins \& Terp. = Terpenoids

\subsection{Antioxidant activity}

The antioxidant activity of methanol extracts of selected plant materials was studied by plotting percentage free radical scavenging versus concentration and $50 \%$ inhibitory concentration (IC50) values for each extract are calculated. Ascorbic acid was used as a standard solution. Figure $1 \mathrm{~A}$ presents the dose-response curve of DPPH radical scavenging activity of plant extracts vs concentration, compared with Ascorbic Acid. The percentage of free radical scavenging is concomitantly increasing with the increase in the concentration of methanol extracts from 20 to $100 \mu \mathrm{g} / \mathrm{ml}$. The concentration of the plant extracts required to inhibit $50 \%$ of DPPH activity (IC50) is shown in Figure 1B. The antioxidant potential is inversely proportional to the IC50 value, the lower the IC50 value, the higher the antioxidant potential, and vice versa. Among the studied plant extracts, the extracts of $\mathrm{N}$. auriculata (46.22 $\mu \mathrm{g} / \mathrm{ml}$ ) and $\mathrm{R}$. nepalensis (48.59 $\mu \mathrm{g} / \mathrm{ml}$ ) showed the highest antioxidant activity as their IC50 were lowest and closer to standard ascorbic acid $(39.85 \mu \mathrm{g} / \mathrm{ml})$. The result reflects that the plants studied above could be a good option in the field of medicine based on the antioxidant property.

\subsection{Total phenolic and flavonoid contents}

The total phenolic contents (TPC) for methanol extracts of selected plant materials were estimated by using the calibration curve and absorbance values (Figure 2a). The methanol extract of $\mathrm{N}$. auriculata showed the highest and $R$. nepalensis showed the second-highest TPC as 1076.73 and $964.56 \mathrm{mg}$ per gram Gallic acid equivalent (mg/g GAE) respectively. While the other plant extracts showed significantly lower value, as shown in Figure 3a. Similarly, total flavonoid contents (TFC) for methanol plant extracts were calculated by using the calibration curve and absorbance values (Figure 2b). The highest TFC was found in N. auriculata and R. nepalensis as 40.8 and $39.06 \mathrm{mg}$ per gram quercetin equivalent (mg/g QE) respectively. Furthermore, the extract of L. wallichiana (35.63 mg/g QE) and E. arborescens (32.41 mg/g QE) also showed a significant amount of total flavonoid content (Figure 3b). The correlation of antioxidant potential (IC50 values) with total phenolic and flavonoid contents of the methanolic plant extracts are shown in Table 3. Phenolic compounds are potent chain-breaking antioxidant which scavenges free radicals due to their hydroxyl groups. Flavonoids are a group of 
polyphenolic compounds, they possess a broad spectrum of chemical and biological activities, including scavenging of reactive oxygen species due to their phenolic hydroxyl groups and are effective antioxidants. The extracts of N. auriculata and R. nepalensis showed the most significant antioxidant potential, which also has the highest total phenolic and total flavonoid contents. These indicate that the medicinal plants with intense antioxidant activity also demonstrate high total phenolic and flavonoid contents.

\subsection{Antibacterial Activity}

Pathogenic bacteria cause many diseases to human beings and dysentery, tuberculosis, respiratory infections are the most common. Antimicrobial agents present in the plant extracts inhibit or kill the growth of such microorganism. The antimicrobial activity of the plant extracts is evaluated by calculating the zone of inhibition (ZOI); the area around the antimicrobial disk where there is no growth of microorganism takes place is called ZOI. The antibacterial activities of the methanol plant extracts were observed against Gram-negative bacteria (Escherichia coli ATCC 25922) and Gram-positive bacteria (Staphylococcus aureus ATCC 25923) which are shown in Table 4. The extract of E. arborescens showed the highest ZOI against both types of bacteria, which were 11 and $14 \mathrm{~mm}$ for Escherichia coli (E. coli) and Staphylococcus aureus (S. aureus) respectively. Similarly, the extract of R. nepalensis, N. auriculata and $\mathrm{H}$. nepalense were found to be active for the inhibition of the growth of both strains of bacteria used. Moreover, the methanol extract of $\mathrm{Z}$. armatum, L. wallichiana, and R. cordifolia were found to be resistant against Grampositive strains only. The absence of ZOI in the extract of $\mathrm{P}$. acinosa representing no antimicrobial activity. Out of the two strains, Gram-positive bacteria are inhibited more effectively than the Gram-negative bacteria.
This fact can be described by the presence of a unique outer membrane that hinders the penetration of extract in the cell in Gramnegative bacteria which is lacking in Grampositive bacteria (Biswas, 2013). These significant values of ZOI for the methanol extracts of E. arborescens, R. nepalensis, N. auriculata, and $\mathrm{H}$. nepalense confirm their antimicrobial activity, i.e. the plants can be used to cure the diseases caused by E. coli and $\mathrm{S}$. aureus bacteria.

\subsection{Brine Shrimp Toxicity Assay}

Brine shrimp lethality assay is a convenient approach for the estimation of the toxic potential of plants and their extracts being rapid, cheaper, and straightforward. Bioactive compounds show toxicity towards newly hatched Brine shrimp larvae (A. salina Leach). The le $\neg$ thal concentration of plant extracts that kills $50 \%$ of the exposed popula 7 tion of A. salina (LC50) values in $\mu \mathrm{g} / \mathrm{ml}$ is determined. The plant extracts having LC50 values below $1000 \mu \mathrm{g} / \mathrm{ml}$ are supposed to be pharmacologically active, and the extracts with LC50 values more than $1000 \mu \mathrm{g} / \mathrm{ml}$ are non-toxic ((Mayer et al., 1982). The results of the brine shrimp toxicity assay are shown in Table 5 . The degree of lethality of the extracts was concentration-dependent, i.e. the maximum mortalities occurred at a concentration of $1000 \mu \mathrm{g} / \mathrm{mL}$ and least at the concentration of $10 \mu \mathrm{g} / \mathrm{mL}$. The extract of Z. armatum $(6.3$ $\mu \mathrm{g} / \mathrm{mL})$ and $\mathrm{H}$. nepalense $(33.88 \mu \mathrm{g} / \mathrm{mL})$ were found to be most cytotoxic against brine shrimps as their LC50 values were found to be lower than $100 \mu \mathrm{g} / \mathrm{mL}$. Furthermore, the extracts of L. wallichiana (138.04 $\mu \mathrm{g} / \mathrm{mL})$ and $P$. acinosa $(177.82 \mu \mathrm{g} / \mathrm{mL})$ also showed significant lethality to brine shrimp. The toxicity assay of the plant extracts correlates directly with cytotoxic and antitumor properties (Hamidi, 2014). This study gives the preliminary idea of the presence of cytotoxic and perhaps the potent antitumor constituents in the plants. 
Table 3: Correlation of total phenolic contents, flavonoid contents and $\mathrm{IC}_{50}$ of methanol plant extracts

\begin{tabular}{|c|c|c|c|}
\hline Plant extracts & $\begin{array}{l}\text { Free radical scavenging } \\
\qquad \mathrm{IC}_{50}(\mu \mathrm{g} / \mathrm{ml})\end{array}$ & $\begin{array}{c}\text { Total phenolic contents } \\
\text { (mg/g QE) }\end{array}$ & $\begin{array}{c}\text { Total flavonoid contents } \\
\text { (mg/g QE) }\end{array}$ \\
\hline Erythrina arborescens & 477.55 & 382.93 & 32.41 \\
\hline Heracleum nepalense & 178.06 & 339.13 & 7.47 \\
\hline Ligusticopsis wallichiana & 134.84 & 107.93 & 35.63 \\
\hline Nephroleps auriculata & 46.22 & 1076.73 & 40.8 \\
\hline Phytolocca acinosa & 226.35 & 92.28 & 7.68 \\
\hline Rubia cordifolia & 357.9 & 128.48 & 8.52 \\
\hline Rumex nepalensis & 48.59 & 964.56 & 39.06 \\
\hline Zanthoxylum armatum & 117.04 & 291.95 & 10.86 \\
\hline
\end{tabular}

Table 4: Antimicrobial screening results of methanol plant extracts

\begin{tabular}{|c|c|c|c|}
\hline S.N & Plant Extract & Bacteria & $\begin{array}{c}\text { ZOI (mm) of extracts at } 100 \\
\mathrm{mg} / \mathrm{ml}\end{array}$ \\
\hline \multirow{2}{*}{1.} & \multirow{2}{*}{ Erythrina arborescens } & E. coli & 11 \\
\hline & & S. aureus & 14 \\
\hline \multirow{2}{*}{2.} & \multirow{2}{*}{ Heracleum nepalense } & E. coli & 6 \\
\hline & & S. aureus & 8 \\
\hline \multirow{2}{*}{3.} & \multirow{2}{*}{ Ligusticopsis wallichiana } & E. coli & - \\
\hline & & S. aureus & 9 \\
\hline \multirow[b]{2}{*}{4.} & \multirow{2}{*}{ Nephroleps auriculata } & E. coli & 4 \\
\hline & & S. aureus & 7 \\
\hline \multirow{2}{*}{5.} & \multirow{2}{*}{ Phytolocca acinosa } & E. coli & - \\
\hline & & S. aureus & - \\
\hline \multirow{2}{*}{6.} & \multirow{2}{*}{ Rubia cordifolia } & E. coli & - \\
\hline & & S. aureus & 8 \\
\hline \multirow{2}{*}{7.} & \multirow{2}{*}{ Rumex nepalensis } & E. coli & 4 \\
\hline & & S. aureus & 6 \\
\hline \multirow{4}{*}{8.} & \multirow{2}{*}{ Zanthoxylum armatum } & E. coli & - \\
\hline & & S. aureus & 4 \\
\hline & \multirow{2}{*}{$\begin{array}{l}\text { Ofloxacin } \\
\text { (standard) }\end{array}$} & E. coli & 14 \\
\hline & & S. aureus & 18 \\
\hline
\end{tabular}

$(-)=$ absence of antibacterial activity, ZOI = Zone of Inhibition, E.coli: Gram-negative bacteria, S.aureus: Grampositive bacteria, Ofloxacin (antibiotic) as positive control 
Table 5: Brine shrimp lethality assay of methanol plant extracts.

\begin{tabular}{|c|c|c|c|c|c|}
\hline S.N & Plant extract & $\begin{array}{l}\text { Concentration } \\
\quad(\mu \mathrm{g} / \mathrm{mL})\end{array}$ & $\begin{array}{l}\text { No. of } \\
\text { subject }\end{array}$ & $\begin{array}{c}\text { Average no. of survival } \\
\text { out of } 10\end{array}$ & $\begin{array}{c}\mathrm{LC}_{50} \\
(\mu \mathrm{g} / \mathrm{mL})\end{array}$ \\
\hline \multirow{3}{*}{1.} & \multirow{3}{*}{ Erythrina arborescens } & 10 & 10 & 10 & \multirow{3}{*}{912.01} \\
\hline & & 100 & 10 & 9.67 & \\
\hline & & 1000 & 10 & 4 & \\
\hline \multirow{3}{*}{2.} & \multirow{3}{*}{ Heracleum nepalense } & 10 & 10 & 2.33 & \multirow{3}{*}{33.88} \\
\hline & & 100 & 10 & 0.3 & \\
\hline & & 1000 & 10 & 0 & \\
\hline \multirow{3}{*}{3.} & \multirow{3}{*}{ Ligusticopsis wallichiana } & 10 & 10 & 9.33 & \multirow{3}{*}{138.04} \\
\hline & & 100 & 10 & 7.67 & \\
\hline & & 1000 & 10 & 0 & \\
\hline \multirow{3}{*}{4.} & \multirow{3}{*}{ Nephrolepsis auriculata } & 10 & 10 & 10 & \multirow{3}{*}{$1.41 \times 10^{16}$} \\
\hline & & 100 & 10 & 9.67 & \\
\hline & & 1000 & 10 & 9.33 & \\
\hline \multirow{3}{*}{5.} & \multirow{3}{*}{ Phytolocca acinosa } & 10 & 10 & 9.97 & \multirow{3}{*}{177.82} \\
\hline & & 100 & 10 & 9 & \\
\hline & & 1000 & 10 & 0 & \\
\hline \multirow{3}{*}{6.} & \multirow{3}{*}{ Rubia cordifolia } & 10 & 10 & 10 & \multirow{3}{*}{489.78} \\
\hline & & 100 & 10 & 8.67 & \\
\hline & & 1000 & 10 & 3.33 & \\
\hline \multirow{3}{*}{7.} & \multirow{3}{*}{ Rumex nepalensis } & 10 & 10 & 9.67 & \multirow{3}{*}{16982.4} \\
\hline & & 100 & 10 & 9.33 & \\
\hline & & 1000 & 10 & 7.33 & \\
\hline \multirow{3}{*}{8.} & \multirow{3}{*}{ Zanthoxylum armatum } & 10 & 10 & 5 & \multirow{3}{*}{6.31} \\
\hline & & 100 & 10 & 1 & \\
\hline & & 1000 & 10 & 0 & \\
\hline
\end{tabular}
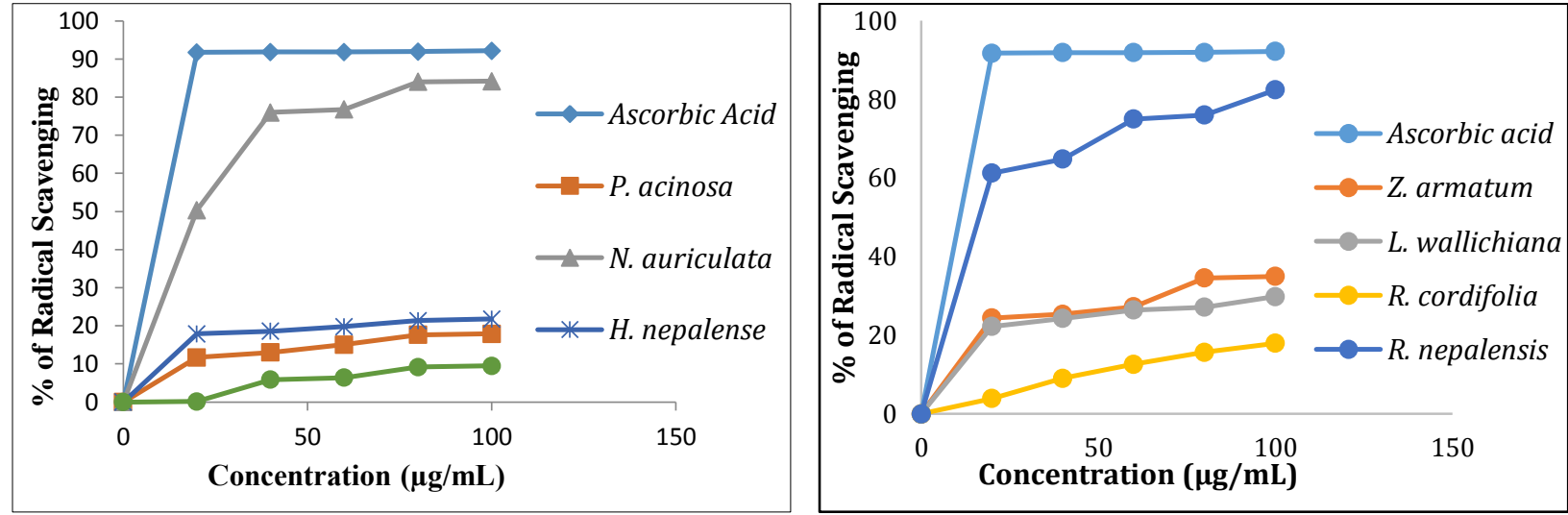

Figure 1A: Percentage scavenging of DPPH free radical by plant extracts vs Concentration $(\mu \mathrm{g} / \mathrm{mL})$ 


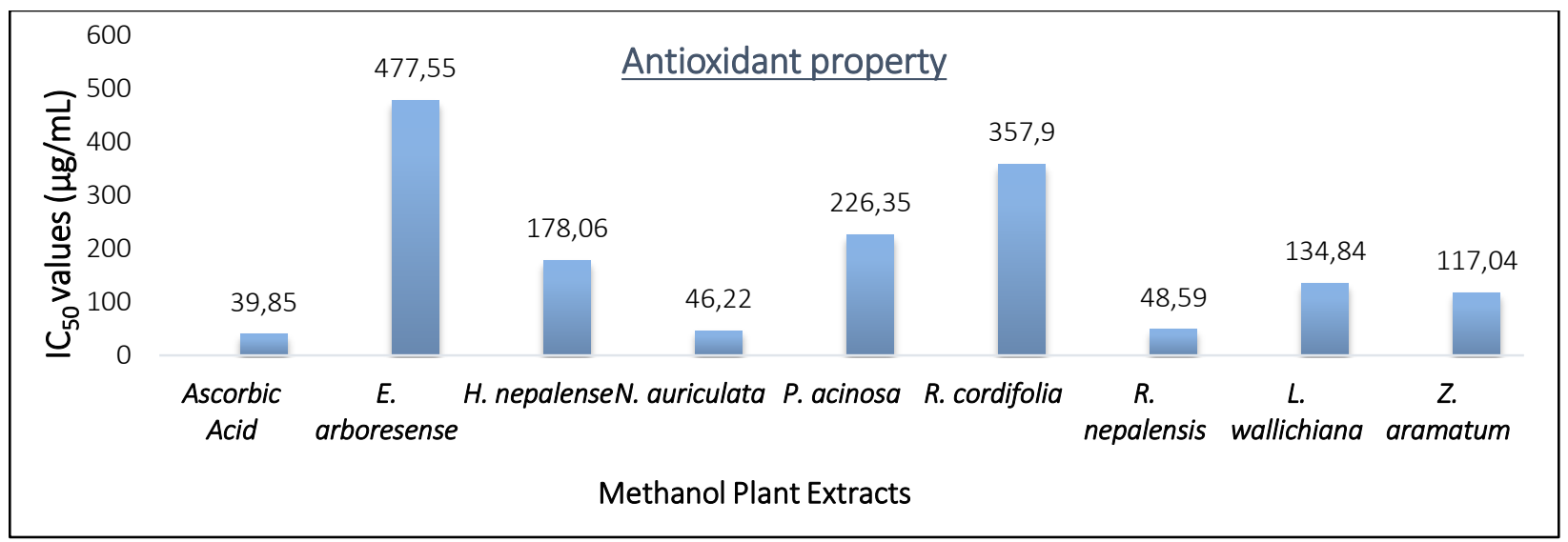

Figure 1B: $I_{50}$ values $(\boldsymbol{\mu g} / \mathbf{m L})$ for methanol plant extracts compared with ascorbic
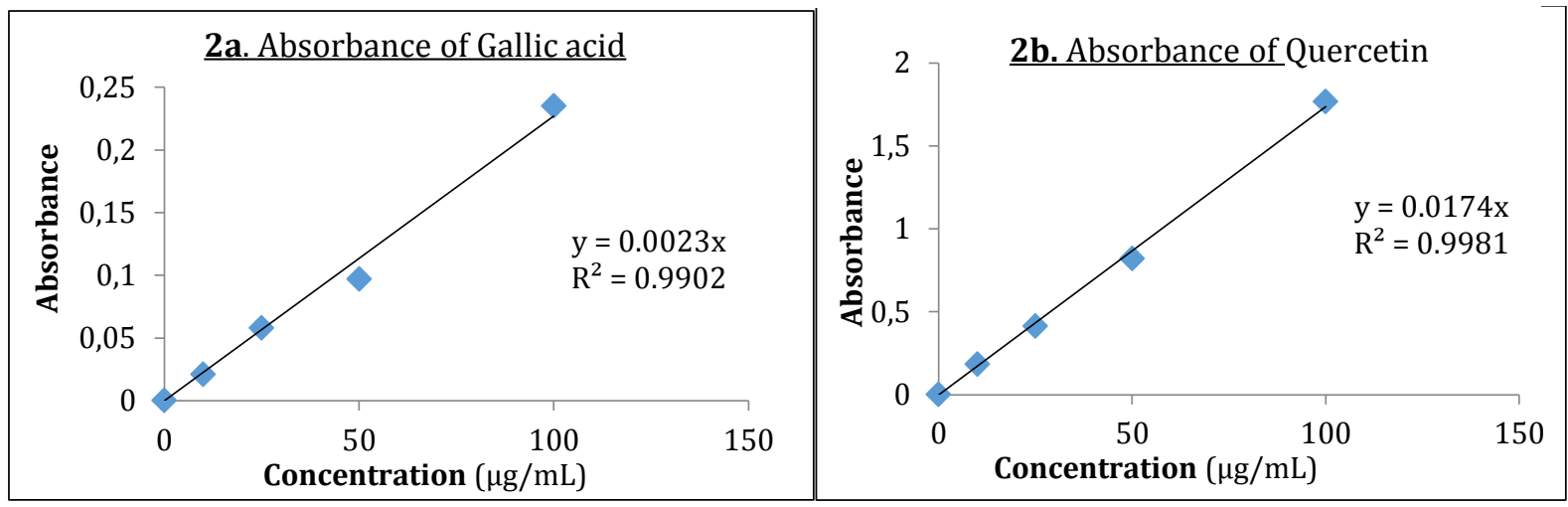

Figure 2: Calibration curve for total phenolic and total flavonoid content determination
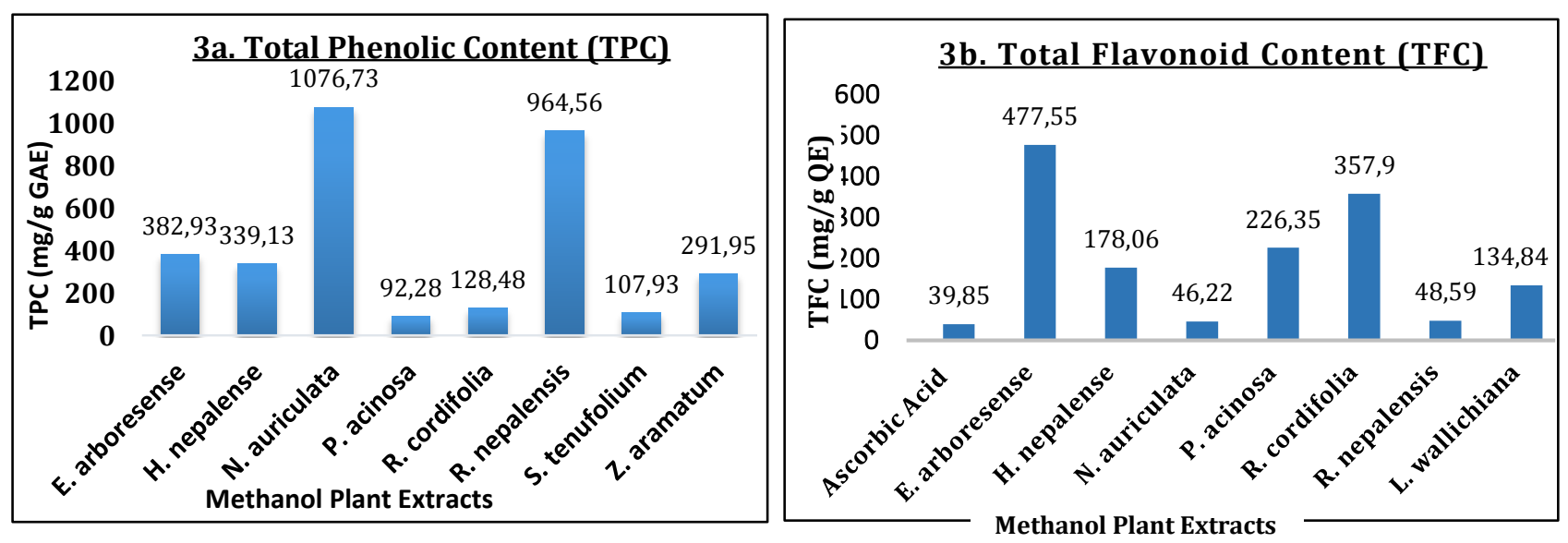

Figure 3: Total phenolic content (TPC) and total flavonoid content (TFC) of methanol plant extracts 


\section{Conclusion}

The phytochemical screening of methanol extract of the plants divulged the presence of essential phytoconstituents; flavonoids, alkaloids, glycosides, saponins, terpenoids, reducing sugars, polyphenols, and quinones. The IC50 values of the methanol extract of $\mathrm{N}$. auriculata and R. nepalensis were found to be nearly equal to the standard ascorbic acid indicating these plants are the potent source of antioxidant. Furthermore, the extracts of N. auriculata and R. nepalensis also showed the highest total phenolic and total flavonoid contents among the selected plant materials. The mechanism of antioxidant activity of the plant extracts may be due to the presence of phytochemicals, flavonoids, and polyphenols. As the phenolic and flavonoid compounds are known to minimize the risk of oxidative stress-induced diseases, the methanol extracts of these plants could be used to develop different types of medicine that may prevent the cell damage (antioxidant).

The antibacterial activity of the plant extracts was evaluated by calculating the zone of inhibition (ZOI). The extract of E. arborescens ( $11 \& 14 \mathrm{~mm}$ ), H. nepalense (6 \& $8 \mathrm{~mm}$ ), N. auriculata (4 \& $7 \mathrm{~mm}$ ), and R. nepalensis (4\& $6 \mathrm{~mm}$ ) showed significant antibacterial activity against both Gramnegative bacteria (E. coli) and Gram-positive bacteria (S. aureus) respectively. The significant values of ZOI for the methanol extracts of the plants indicating they can be used to cure the diseases caused by Escherichia coli and Staphylococcus aureus bacteria. The brine shrimp bioassay of the plant extracts showed that the extract of $\mathrm{Z}$. armatum $(6.31 \mu \mathrm{g} / \mathrm{mL}), \mathrm{H}$. nepalense (33.88 $\mu \mathrm{g} / \mathrm{mL})$, L. wallichiana $(138.04 \mu \mathrm{g} / \mathrm{mL})$ and P. acinosa $(177.82 \mu \mathrm{g} / \mathrm{mL})$ were most cytotoxic against brine shrimps and may contain pharmacologically active compounds as its LC50 value are significantly less than $1000 \mu \mathrm{g} / \mathrm{mL}$.

The present work has demonstrated that the methanolic extracts of plants possess promising antioxidant, antibacterial, and cytotoxic potential, thereby endorsed the notion behind the traditional use of the medicinal plants to treat different diseases. However, further, in vitro and in vivo studies as well as isolation and characterization of the active constituents responsible for the observed biological activities are needed to conduct in order to understand the exact mechanisms of such actions.

\section{Acknowledgements}

The authors are grateful to the University Grant Commission (UGC), Bhaktapur, Nepal for financial support, Central department of Chemistry, Tribhuvan University, Kathmandu for providing laboratory facility, and NIST College, Khusibu, Kathmandu for providing laboratory to conduct antibacterial assay test.

\section{Conflicts of Interest}

There is no conflict of interest to disclose.

\section{References}

1. Abdalla, A. E. M., 2007. Egyptian mango by-product 2: Antioxidant and antimicrobial activities of extract and oil from mango seed kernel. Food Chemistry, 103(4), 1141-1152. DOI: 10.1016/j.foodchem.2006.10.026

2. Acharya, S. R., et al. 2014. Antioxidant and Antimicrobial Properties of Leaves of Lyonia ovalifolia Wallich. International Journal of Pharmaceutical \& Biological Archives, 5(4), 76 -81.

3. Adhikary, P., et al. 2011. Phytochemical Screening and Anti-Microbial Properties of Medicinal Plants of Dhunkharka Community, Kavrepalanchowk, Nepal. International Journal of Pharmaceutical \& Biological Archives, 2(6), 1663-1667.

4. Baskar, N., Parimala, D. B., \& Mohan, K. R., 2010. Anti-Cancer Activity of Methanol Extract of Root Bark of Erythrina variegata Linn. International Journal of Toxicological and Pharmacological Research, 2(2). 
5. Biswas, B., et al. 2013. Antimicrobial Activities of Leaf Extracts of Guava (Psidium guajava L.) on Two GramNegative and Gram-Positive Bacteria. International Journal of Microbiology. DOI: $10.1155 / 2013 / 746165$

6. Blois, M. S., 1958. Antioxidant Determinations by the Use of a Stable Free Radical. Nature, 181:1199-1200.

7. Cavalieri, S. J., Rankin, I. D., et al. 2005. Manual of Antimicrobial Susceptibility Testing. American Society for Microbiology, Washington, DC.

8. Ciulei, I., 1982. Practical Manuals on the Industrial Utilization of Medicinal and Aromatic Plants: Methodology for analysis of vegetable drugs. University of Bucarest, 1-10.

9. Devkota, H. P., Adhikari, B., Watanabe, T. \& Yahara, S., 2018. Nonvolatile Chemical Constituents from the Leaves of Ligusticopsis wallichiana (DC.) Pimenov \& Kljuykov and their Free RadicalScavenging Activity. Journal of Analytical Methods in Chemistry, 1-8. DOI:10.1155/2018/1794650.

10. Dingel, J., Reid, W. W., \& Solomons, G. L., 1953. The enzymic degradation of pectin and other polysaccharides. IIApplication of the 'Cup-plate' assay to the estimation of enzymes. Journal of the Science of Food and Agriculture, 4(3):149-155.

11. Dhote, K., Dhote, V., \& Khatri, K., 2015. Phytochemical Screening and Pharmacological Activity in Punica granatum. Asian Journal of Pharmaceutical Education and Research, $4(4), 69-80$.

12. Ghimire, S. K., Sapkota, I. B., Oli, B. R., \& Parajuli, R., 2008. Non-Timber Forest Products of Nepal Himalaya; Database of Some Important Species Found in the Mountain Protected Areas and Surrounding Regions. WWF Nepal,
Kathmandu, Nepal. NTFP of Nepal Himalaya.

13. Gonçalves, S., Moreira, E., Grosso, C., Andrade, P. B., Valentão, P., Romano, A., 2017. Phenolic profile, antioxidant activity and enzyme inhibitory activities of extracts from aromatic plants used in Mediterranean diet. Journal of Food Science and Technology, 54(1):219-227. DOI: $10.1007 / \mathrm{s} 13197-016-2453-\mathrm{z}$

14. Hamidi, M. R., Jovanova, B., Panovska, T. K., 2014. Toxicological evaluation of the plant products using Brine Shrimp (Artemia salina L.). Macedonian pharmaceutical bulletin, 60 (1) 9 - 18 .

15. Jamuna, S., Paulsamy S., \& Karthika, K., 2012. Screening of in vitro antioxidant activity of methanolic leaf and root extracts of Hypochaeris radicata L. (Asteraceae). Journal of Applied Pharmaceutical Science, 02 (07), 149154.

16. Joshi, R. K., 2016. Chemical constituents of leaf essential oils of Heracleum candicans Wall. ex DC from western Himalaya of Uttarakhand, India. American Journal of Essential Oils and Natural Products, 4(2), 01-04.

17. Kalita, P., Tapan, K. B., Pal, T. K., Kalita, R., 2013. Estimation of Total Flavonoids content and Anti-oxidant activities of Methanolic Whole plant extract of Biophytum Sensitivum Linn. Journal of Drug Delivery and Therapeutics, 3(4), 33-37. DOI: $10.22270 / j d d t . v 3 i 4.546$

18. Kasote, D. M., Katyare, S. S., Hegde, M. V., and Bae, H., 2015. Significance of Antioxidant Potential of Plants and its Relevance to Therapeutic Applications. International Journal of Biological. Science, 11(8), 982-991. DOI: 10.7150/ijbs.12096

19. Kumar, S., Joseph, L., George, M., \& Bharti, V., 2011. Antimicrobial Activity of Methanolic Extract of Rumex Nepalensis Leaves. International Journal 
of Pharmacy and Pharmaceutical Sciences, 3(4), 240-242.

20. Kunwar, R. M., et al. 2011. Medicinal and Aromatic Plants Network (MAPsNet) Nepal: An open access digital database. Banko Janakari, 21(1) DOI: 10.3126/banko.v21i1.9064

21. Kunwar, et al. 2013. Medicinal plants, traditional medicine, markets and management in far-west Nepal. Journal of Ethnobiology and Ethnomedicine, 9:24.

22. Manandhar, S., Luitel, S., \& Dahal, R. K., 2019. In Vitro Antimicrobial Activity of Some Medicinal Plants against Human Pathogenic Bacteria. Journal of Tropical Medicine, 1-5. DOI: $10.1155 / 2019 / 1895340$

23. Meena, A. K., Bhavana, P., Panda, P., Sannd, R., and Rao, M. M., 2010. A review on Rubia cordifolia: Its phyto constituents and therapeutic uses. Drug Invention Today, 2(5), 244-246.

24. Meyer, B. N., et al. 1982. Brine shrimp: a convenient general bioassay for active plant constituents. Planta Medica, 45(5), 31-34. DOI: $10.1055 / \mathrm{s}-2007-971236$

25. Nepal: General Info, Federation of Nepalese Chambers of Commerce and Industry (FNCCI).

26. Oliveira de, A. C., et al. 2009. Total phenolic content and free radical scavenging activities of methanolic extract powders of tropical fruit residues. Food Chemistry, 115(2), 469475.

DOI:

10.1016/j.foodchem.2008.12.045

27. Parajuli, R. R., 2013. Study on Local Uses of Medicinal Plants in Nayabazar, Pyang and Jamuna VDCs of Ilam District. Nepal Journal of Science and Technology, 14(1), 57-66. DOI: 10.3126/njst.v14i1.8923

28. Parajuli, S., et al. 2012. Antioxidant Activity, Total Phenol and Flavonoid
Contents in Some Selected Medicinal Plants of Nepal. Journal of Health and Allied Sciences, 2(1), 27-31.

29. Pliszko, A. \& Klich, S., 2018. A new record of Phytolacca acinosa (Phytolaccaceae) in Poland. Acta Mus. Siles. Sci. Natur., 67: 181-183. DOI: 10.2478/cszma-2018-0013

30. Rukmini, K., \& Suvarnalatha, P. D., 2014. GC-MS Analysis and Phytochemical Screening of a rare Pteridophyte Nephrolepis Cardifolia (L.) Presl. from Tirumala Hills. International Journal of Pharma Research \& Review, 3(12), 1319.

31. Saxena, M., et al. 2012. Flavonoids and phenolic acids as antioxidants in plants and human health. International Journal of Pharmaceutical Sciences Review and Research, 16(2):130-134.

32. Saxena, M., Saxena, J., 2013. Phytochemistry of Medicinal Plants. Journal of pharmacognosy and Phytochemistry, 1(6), 168-182

33. Sen, S., et al. 2010. Free Radicals, Antioxidants, Disease and Phytomedicines: Current Status and future Prospect. International Journal of Pharmaceutical Sciences Review and Research, 3(1), 91-100.

34. Shahidi, F, Zhong, Y., 2010. Novel antioxidants in food quality preservation and health promotion. European Journal of Lipid Science and Technology. 112(9), 930-940. DOI: 10.1002/ejlt.201000044

35. Shrestha, B. P., et al. 2019. Biodiversity Profile of the API Nampa Conservation Area, Darchula. Department of National Parks and Wildlife Conservation, Kathmandu, Nepal, 1-108.

36. Ullah, S., et al. 2011. Antibacterial activity of some selected plants of Swat valley. Bioscience Research, 8(1), 15-18. 
37. Waterhouse, A. L., 2003. Determination of Total Phenolics. Current Protocols in Food Analytical Chemistry. John Wiley \& Sons, New York. DOI: 10.1002/0471142913.fai0101s06

38. Yuan, H., Ma, Q., Li Y., \& Piao, G., 2016. The Traditional Medicine and Modern Medicine from Natural Products. Molecules, 21(5): $559 . \quad$ DOI: 10.3390/molecules21050559

39. Zaidan, M. R. S., et al. 2005. In vitro screening of five local medicinal plants for antibacterial activity using disc diffusion method. Tropical Biomedicine, 22(2), 165-170. 